\title{
THE EMPEROR OF ALL ACTUALITIES: S.377 JURISPRUDENCE IN COMPARATIVE CONTEXT
}

\author{
Nihal Sahu*
}

"A model is a lie that helps you see the truth." - Howard Skipper ${ }^{1}$

"The more perfect a power is, the more difficult it is to quell." - Saint Aquinas

\begin{abstract}
$\underline{\text { ABSTRACT }}$
Navtej Singh Johar v. Union of India revolutionized, contemporized, and revitalized our Equality jurisprudence. In this essay, I argue that Supreme Court's jurisprudence culminating in Navtej is best understood as one in a long line of cases leading us to an expanded notion of equality (Articles 14 and 15) in the context of a gradual and ongoing judicial acceptance of academic scholarship on a global theory of sexual sovereignty. I address the history behind S. 377 including colonial history, early jurisprudence, attempts at repeal, the High Court decision in Naz Foundation, the reversal in Koushal, and the intermediary steps of NALSA and Puttaswamy leading to redemption in Navtej. I also examine the Indian Supreme Court's changing attitudes towards comparative constitutionalism with a special emphasis on foreign law, examining the global theory and comparing Navtej with its parallel in Lawrence v. Texas with a focus on Spatial Privacy, Deliberative Autonomy, and Expressive Liberty. I further examine the constitutionality of S. 377 in a neutral manner while considering parallels with Lawrence, noticing how a utopian reading of Lawrence maps perfectly onto the singular approach in $N a z$ and the various approaches in Navtej. I also note the most distinct contributions to our jurisprudence made by the bench in Navtej. In doing so, I examine the changes in our Article 14 and Article 15 jurisprudences, our Right to Privacy jurisprudence emanating from Article 21, and the varying judicial attitudes that lead to such changes. I conclude with a note on the importance of clear rulemaking, clarity, consistency, and respect for the separation of powers in judicial analysis.
\end{abstract}

\footnotetext{
* First-year B.A. LLB (Hons.) student at the National University of Advanced Legal Studies, Kochi. This paper would not have been written, edited, or published without the help of my professors and friends at NUALS, among whom are the inimitable Prof. (Dr.) Jacob Joseph, who year after year instills respect for law, research, precision, and authenticity in his students; Prof. (Dr.) Matthew Joseph, whose lectures are a tribute to the use of the English language; the delightful Anita Elizabeth, whose assistance in my research has been invaluable; Mekha Vijayakumar, Nitya Nair, Vedantha Sai, Shereene Mohammed and Vaidehi Menon whose sharp criticism and suggested revisions improved this paper immeasurably; and Nikhil Mahadeva, who line-edited the final draft with characteristic patience and sagacity. I also owe immense gratitude to my parents, for reasons that are all too obvious.

${ }^{1}$ Siddhartha Mukherjee, The Emperor of All Maladies: A Biography of Cancer (Simon and Schuster 2011) 139
} 
On $6^{\text {th }}$ September 2018, in Navtej Singh Johar v. Union of India ${ }^{2}$, the Supreme Court read down S. 377 of the Indian Penal Code to decriminalize homosexual sex between consenting adults, ruling that the provision was "irrational, indefensible and manifestly arbitrary."3 The judgment provoked extravagant praise of liberty ${ }^{4}$ and was celebrated as a baffling reinvention of constitutional law. This, on its own, does not provoke interest. Unlike lesser jurisdictions, the reinvention of constitutional law is seen as a commonplace event in Indian jurisprudence. Navtej, far from being banal, is the culmination of half-a-century of legal scholarship and constitutional metamorphosis.

I will argue that Navtej was made possible by a global revolution of civil rights law regarding sexual orientation. In doing so, my principal goal is not to evaluate Navtej, but instead to better understand it in the context of other dramatic decisions in Indian and global jurisprudence. ${ }^{5}$ I will review the path that made Navtej possible, from the inception of the statutory provision to the present day, and critically analyze the holding in Navtej and place it in the context of a gradual and ongoing acceptance of the global theory of sexual sovereignty ${ }^{6}$ that is based on the US Supreme Court's groundbreaking opinion in Lawrence v. Texas ${ }^{7}$. Further, this essay will explore where Navtej might lead constitutional law as well as LGBT rights in India and internationally.

We begin by reviewing the origins of S. 377. The prohibition of certain homosexual acts in British Criminal Law began in 1534, with legislation during the reign of Henry VIII prohibiting the 'detestable and abominable Vice of Buggery committed with mankind or beast,' drawing inspiration from Leviticus ${ }^{8}$ in the Bible which has been described as "the most influential

\footnotetext{
${ }^{2}$ Navtej Singh Johar v Union of India AIR 2018 SC 4321

3 ibid 9240 (Misra, C.J.I., and Khanwilkar, J.,)

${ }^{4}$ See Payal Gwalani, 'Supreme Court partially strikes down Section 377: No prejudice, only pride' (Mumbai Mirror, 7 September 2018) <https://mumbaimirror.indiatimes.com/mumbai/other/no-prejudice-onlypride/articleshow/65712755.cms> accessed 7 December 2018

${ }^{5}$ For a similar analysis of Lawrence, See Cass R Sunstein, 'What Did Lawrence Hold? Of Autonomy, Desuetude, Sexuality, and Marriage’ (2003) (John M. Olin Program in Law and Economics Working Paper No 196)

${ }^{6}$ See Sonia K Katyal, 'Sexuality and Sovereignty: the Global Limits and Possibilities of Lawrence' (2006) 14 William and Mary Bill of Rights Law Journal 1429, 1460

${ }^{7}$ Lawrence $v$ Texas 539 US 558 (2003) (legalized homosexual conduct in every US State and Territory)

${ }^{8}$ Leviticus 18:22 and 20:13 read:

"You shall not lie with a male as with a woman. It is an abomination."

"If a man lies with a male as with a woman, both of them have committed an abomination; they shall be put to death, their blood is upon them."
} 
condemnation of male homosexual acts in world history." 9 The provision, a continuation of ecclesiastical law, was part of Henry VIII's separation of the English church from Rome and was meant to strip the Catholic clergy of immunity from punishment by royal officials. ${ }^{10}$ Edward Coke, compiling English law in the late $17^{\text {th }}$ century, wrote that buggery comprised acts "committed by carnal knowledge against the ordinance of the Creator, and order of nature..." making evident the origin of the statutory language in S. 377. ${ }^{11}$ Macaulay's original draft of the provision, found as clause 361 in the Draft Code of 1837, however, did not use the words 'order of nature,' and criminalized the touching of any person or animal to 'gratify unnatural lust.' 12 The words 'against the order of nature' were not added until the provision became S. 377 of the Indian Penal Code of $1860 .{ }^{13}$ The provision as it stands today reads:

"377. Unnatural offences. - Whoever voluntarily has carnal intercourse against the order of nature with any man, woman or animal, shall be punished with imprisonment for life, or with imprisonment of either description for a term which may extend to ten years, and shall also be liable to fine.

Explanation. - Penetration is sufficient to constitute the carnal intercourse necessary to the offence described in this section."

The provision leaves the phrases "unnatural" and "order of nature" undefined. Judicial interpretation arrived in the form of Khanu v. Emperor ${ }^{15}$ which noted that certain acts were against the order of nature "because the natural object of carnal intercourse is that there should be the possibility of conception of human beings, which in the case of coitus per $\operatorname{OS}^{16}$ is impossible." 17 Khanu conclusively brought oral sex within the ambit of S. 377 and introduced what we shall refer to as the 'possibility of conception' test, stating that carnal intercourse where there is no possibility of the conception of human beings is 'against the order of nature' and a criminal offence under S. $377 .{ }^{18}$

\footnotetext{
${ }^{9}$ Douglas E Sanders, '377 and the Unnatural Afterlife of British Colonialism in Asia' (2009) 4 Asian Journal of Comparative Law 1(7), 2

10 ibid 6

11 ibid 7

${ }^{12}$ Sreekumar Kodiyath, 'Deciphering the Dichotomy: Supreme Court of India's Contrasting Jurisprudence on Transgender Rights and Homosexuality' <https://ssrn.com/abstract=2655864> accessed 4 January 2019, 3

13 ibid

${ }^{14}$ Indian Penal Code 1860, s. 377

${ }^{15}$ Khanu v Emperor AIR 1925 Sind 286

16 'Coitus per OS' refers to oral sex

${ }^{17}$ ibid

${ }^{18}$ Kodiyath (n 12) 4
} 
Khanu's jurisprudential progeny created pedantic and impractical distinctions, making almost every non-procreative sexual act a criminal offence. Take, for example, Lohana Vasantlal Devchand v. The State ${ }^{19}$, which noted, with infinite patience, that 'if the stage of aforesaid act was for stimulating the sex urge, it may be urged that it was only a prelude to carnal intercourse ${ }^{20}$ but that since the intent was "to appease his sexual urge and to satisfy his passions, it would amount to an offence, punishable under this act." ${ }^{21}$ Lohana laid down what we may call the 'imitative test' where acts that were substitutes for coitus were penalised, while acts that were merely preludes to sexual intercourse for the purpose of procreation, were not. ${ }^{22}$ Gautam Bhatia notes the primary effect of this distinction, for it "penalized some forms of sexual expression among heterosexuals, while necessarily prohibiting any sexual intimacy between homosexuals." 23

The issue of LGBT rights has a precarious foothold in national debates in India. ${ }^{24} \mathrm{~A}$ number of incidents, including violent right-wing Hindu protests against a movie portraying a lesbian relationship in 1998, the arrest of HIV/AIDS outreach workers at Lucknow in 2001, the entrapment of a number of men by the Lucknow police in 2006, and a letter supporting the challenge to S. 377 signed by a number of celebrities led by Vikram Seth; leading to support in liberal media for decriminalization. ${ }^{25}$ Reform by Parliament always seemed unlikely because of a lack of popular support as well as reactionary legislators, as displayed during multiple legislative attempts by Dr. Shashi Tharoor, a Member of Parliament, to decriminalize homosexual conduct. ${ }^{26}$

The most important shift in jurisprudence arose in the case of Naz Foundation v. NCT of Delhi ${ }^{27}$, when a Division Bench of the Delhi High Court held that S. 377, to the extent that it

\footnotetext{
${ }^{19}$ Lohana Vasantlal Devchand v The State [1968] 9 CLR 1052

${ }^{20}$ ibid 97

${ }^{21}$ ibid 9

22 ibid

${ }^{23}$ Gautam Bhatia, 'Equal Moral Membership: Naz Foundation and the Refashioning of Equality under a Transformative Constitution' (2017) 1:2 Indian Law Review 115, 118

${ }^{24}$ Sanders (n 9) 39

25 ibid

${ }^{26}$ Apurva Vishwanath, 'In Parliament, Shashi Tharoor's valiant fight to change section 377' (The Print, 8 January 2018) <https://theprint.in/politics/parliament-shashi-tharoor-valiant-fight-change-section-377/27435/> accessed 8 January 2019

${ }^{27}$ Naz Foundation v NCT of Delhi [2009] 160 DLT 277 (High Court of Delhi)
} 
"criminalises consensual sexual acts of adults in private, is violative (sic) of Articles 21, 14 and 15 of the Constitution." ${ }^{28} \mathrm{Naz}$ led a fundamental change in Article 14 jurisprudence.

Before $\mathrm{Naz}$, Article 14 jurisprudence had revolved primarily around a three-pronged test that determined whether a classification was reasonable: first, the absence of arbitrariness ${ }^{29}$, artificiality, or evasiveness; second, the existence of intelligible differentia or, more clearly put, 'some real and substantial distinction' between those included and those excluded in the classification; and third, the differentia adopted "must have a rational or reasonable nexus" with a "legitimate state interest." 30 The Article 14 test, thus far, involved substantial deference to the political branches as to what a 'legitimate state interest' was, and what the state could do in pursuit of that interest. ${ }^{31}$ In $\mathrm{Naz}$, the formalistic limits of that Article 14 test were exploded in favor of a broad conception of Fundamental Rights. Naz Foundation declared that while Courts should "ordinarily defer to the wisdom of the legislature," "when matters of high constitutional importance" are at issue, the courts were justified in giving "considerably less deference to the legislature than would otherwise be the case." ${ }^{, 32}$ In $\mathrm{Naz}$, the judicial analysis was not confined to the mere formal terms of the classification, but included the repercussions of such a classification. In other terms, the effect of the classification was now fair game, and the Court could take cognizance of what we may call the 'effective' classification in determining whether Article 14 had been violated.

In $\mathrm{Naz}$, Articles 14, 15, and 16 were considered together, as separate facets of the same "equality principle." 33 The Article 15(1) prohibition on sex based discrimination was read to implicitly include a prohibition on sexual orientation. ${ }^{34}$ Article 14 classifications, to the extent that they discriminated on the basis of any of the prohibitions in Article 15 (including the new interpretation of 'sex' to include 'sexual orientation'), were deemed to require 'strict scrutiny. ${ }^{35}$ The strict scrutiny test is a concept borrowed from American jurisprudence. ${ }^{36}$ To

\footnotetext{
${ }^{28}$ ibid 132

${ }^{29}$ See Chintranjit Lal Choudhry v Union of India 1950 SCR 869 (Justice Fazl Ali, concurring, observed that a classification that is arbitrary and without basis is no classification at all); See also EP Royappa $v$ State of Tamil Nadu 1974 SCR (2) 348 (where arbitrariness was used as a 'free standing' Article 14 test); For a discussion of arbitrariness, See also Bhatia (n 23) 123

${ }^{30}$ MP Jain, Indian Constitutional Law, vol 1 (6 ${ }^{\text {th }}$ edn, LexisNexis 2013) 1233

${ }^{31}$ Bhatia (n 23) 132

${ }^{32}$ Naz Foundation (n 27) 118

${ }^{33}$ Naz Foundation (n 27) 99

${ }^{34}$ ibid

35 ibid 113

${ }^{36}$ See United States v Carolene Products Co 304 US 144 (2004) (where, in footnote four, different levels of scrutiny were introduced for the first time)
} 
survive a strict scrutiny test, a law must be proportional and reasonable with regard achieving a legitimate state interest. ${ }^{37}$ If it is not, as the Court held S. 377 was not, it is unconstitutional. The Court also noted that it violated the right to privacy in Article 21.

The reasoning in Naz was hardly novel. The uncanny resonance with Lawrence makes this obvious. The judgment in Naz Foundation v. NCT of Delhi was merely a continuation, the next chapter in the global effect of the decision in Lawrence. Sometimes, arguments are ahead of their time. This is illustrated by the fact that the writ petition in Naz was filed at the Delhi High Court in $2001 .^{38}$ After being dismissed for lack of cause of action, it took eight long years for the mode of analysis in Lawrence to become the judicial attitude in $\mathrm{Naz} .{ }^{39}$ Some of the delay, of course, can be ascribed to the incredible slowness of the Indian judiciary as a whole ${ }^{40}$, but some of it must be ascribed to the time it takes for public opinion to shift. ${ }^{41}$ Members of the Court "live in society, and they are inevitably influenced by what society appears to think."

Naz began not as the search for a new model but with the novel innovation firmly in mind. The search had already taken place at the Supreme Court of the United States, in Lawrence, where the facts were "exceedingly simple." ${ }^{43}$ Responding to a private report of a weapons disturbance in a private residence, Houston police entered the residence, where they found both the eventual petitioners, Lawrence and Garner, engaging in a consensual sexual act. ${ }^{44}$ They were tried and convicted "of deviate sexual intercourse in violation of a Texas statute forbidding two persons of the same sex to engage in certain intimate sexual conduct." 45 The State Court of Appeals affirmed the conviction, following Bowers v. Hardwick, ${ }^{46}$ the controlling precedent on the issue. ${ }^{47}$ The Supreme Court of the United States granted certiorari to determine whether the impugned statute violated the Equal Protection Clause or Due Process Clause of the Fourteenth Amendment to the US Constitution. ${ }^{48}$

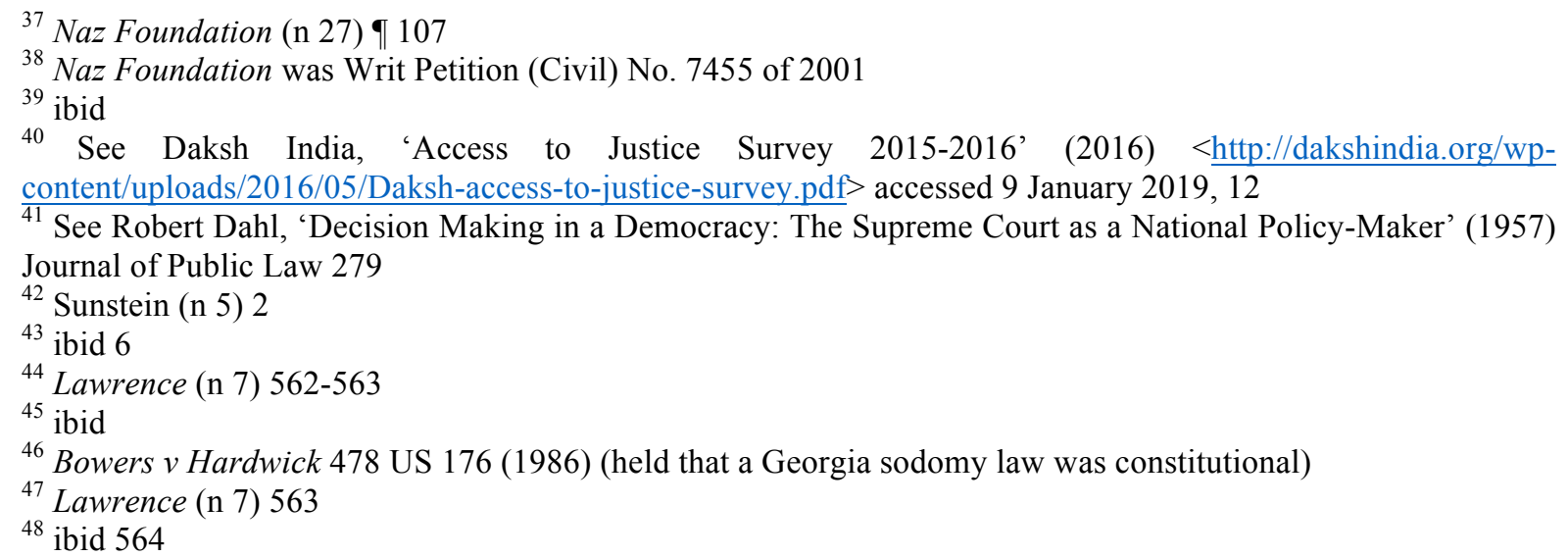


The Opinion of the Court, authored by Justice Anthony Kennedy (now considered, postObergefell, ${ }^{49}$ as the "Thurgood Marshall of gay rights" ${ }^{, 50}$ ), held ${ }^{51}$ that the Texas statute violated the Due Process Clause, which reads:

"[N]or shall any State deprive any person of life, liberty, or property, without due process of law."52

That was, of course, not the only option available to the Court. As Sunstein points out, "The Lawrence Court had three options." ${ }^{53}$ It could invalidate the law on either Due Process or Equal Protection ${ }^{54}$ grounds, or choose to uphold it against both the aforementioned challenges. ${ }^{55}$ The Court chose to invalidate it on Due Process grounds, ${ }^{56}$ but Justice O'Connor's concurring opinion outlined a different path to the same outcome, via the Equal Protection Clause. ${ }^{57}$

Justice O'Connor concluded that, "[w]hen a law exhibits such a desire to harm a politically unpopular group", the Court has applied a "more searching form of rational basis review." If this sounds familiar, it is because the Article 14 reasoning in Naz was originally based on the Equal Protection argument in Justice O'Connor's concurrence. Other similarities emerge, when we note that $N a z$ held that S. 377 violated the Right to Privacy found in Article 21 as well, citing Griswold ${ }^{58}$, a US Supreme Court case that was one of the primary progenitors of Lawrence. ${ }^{59}$ The relevant paragraph in Naz reads:

"The privacy recognises that we all have a right to a sphere of private intimacy and autonomy which allows us to establish and nurture human relationships without interference from the outside community. The way in which one gives expression to one's sexuality is at the core of this area of private intimacy. If, in expressing one's

\footnotetext{
49 Obergefell $v$ Hodges 576 US

${ }^{50}$ Ivey DeJesus, 'Marriage equality: The breathtaking words of Justice Anthony Kennedy' (Penn Live, 26 June $2015)<$ https://www.pennlive.com/midstate/index.ssf/2015/06/gay_marriage_supreme_court_ant.html $>$ accessed 9 January 2019 (quoting an interview with John Culhane, professor of law at Widener Law School)

${ }^{51}$ Lawrence (n 7) 567 ("It suffices for us to acknowledge that adults may choose to enter upon this relationship in the confines of their homes and their own private lives and still retain their dignity as free persons. When sexuality finds overt expression in intimate conduct with another person, the conduct can be but one element in a personal bond that is more enduring. The liberty protected by the Constitution allows homosexual persons the right to make this choice.")

${ }^{52}$ US Constitution, Amendment XIV, §1

${ }^{53}$ Sunstein (n 5) 6

${ }^{54}$ US Constitution, Amendment XIV, $§ 1$ ("nor deny to any person within its jurisdiction the equal protection of the laws.")

${ }^{55}$ Sunstein (n 5) 6

${ }^{56}$ Lawrence (n 7) 567

57 ibid 579

${ }^{58}$ Griswold v Connecticut 381 US 479 (1965)

${ }^{59}$ Sunstein (n 5) 2 (“...Lawrence v. Texas is best seen as a successor of Griswold v. Connecticut...”)
} 
sexuality, one acts consensually and without harming the other, invasion of that precinct will be a breach of privacy." 60

Compare this to the relevant paragraph in Lawrence, which reads:

"It suffices for us to acknowledge that adults may choose to enter upon this relationship in the confines of their homes and their own private lives and still retain their dignity as free persons. When sexuality finds overt expression in intimate conduct with another person, the conduct can be but one element in a personal bond that is more enduring. The liberty protected by the Constitution allows homosexual persons the right to make this choice." 61

The focus on the expression of identity, and the protected nature of intimacy as a facet of Privacy are the integral notions in Lawrence, as they are a fundamental facet of Naz. This comparison serves a purpose; one that is relevant for understanding the framework of how comparative constitutionalism is applied in India.

This brings us to the aftermath of $\mathrm{Naz}$, which for all its novelty and analysis, was only a High Court judgment. An appeal was filed, and the Supreme Court reversed Naz in Koushal ${ }^{62}$, a preternaturally ill-received judgment. It faced criticism for both its analysis ${ }^{63}$ and its methodology. ${ }^{6465}$ In a manner entirely uncharacteristic of the Supreme Court of India, it advocated judicial caution in the exercise of judicial review. ${ }^{66}$ In addition to failing to respond to much of the reasoning in $\mathrm{Naz}^{67}$, it featured an approach to foreign law that has been described as "schizophrenic, ${ }^{68}$ noting that the High Court, in its "anxiety" to protect the "so-called right of LGBT persons," "extensively relied upon the judgments of other jurisdictions." ${ }^{69}$ Such foreign judgments, the Court felt, "cannot be applied blindfolded for deciding the

${ }^{60}$ Naz Foundation (n 27) 90 (emphasis added)

${ }^{61}$ Lawrence (n 7) 567 (emphasis added)

${ }^{62}$ Suresh Kumar Koushal v Naz Foundation (2014) 1 SCC 1

${ }^{63}$ See Gautam Bhatia, 'The Unbearable Wrongness of Koushal vs Naz Foundation' (Indian Constitutional Law and Philosophy, 11 December 2013) <https://indconlawphil.wordpress.com/2013/12/11/the-unbearablewrongness-of-koushal-vs-naz-foundation/> accessed 10 January 2019

${ }^{64}$ See Rehan Abeyratne and Nilesh Sinha, 'Insular and Inconsistent: India's Naz Foundation Judgment in Comparative Perspective' (2014) 39 Yale Journal of International Law Online 74 $<$ https://ssrn.com/abstract=2395665> accessed 10 January 2019 (The paper unconventionally refers to Koushal as the "Supreme Court's decision in Naz")

${ }^{65}$ Bhatia (n 23) 140 ("Koushal vs Naz is a difficult case to interpret, primarily because the 98 pages of the judgement consist almost entirely of recapitulating the submissions of counsel and the position of law, with neither an analysis, nor a definite finding, on most of the issues before the Court."); See Siddharth Narrain, 'Lost in Appeal: The Downward Spiral from Naz to Koushal' (2013) 6 NUJS L REV 4575

${ }^{66}$ Koushal (n 62) $\mathbb{} 26$

${ }^{67}$ Bhatia (n 23) 140

${ }^{68}$ Abeyratne and Sinha (n 64) 77

${ }^{69}$ Koushal (n 62) ๆ 52 
constitutionality of the law enacted by the Indian legislature." ${ }^{, 70}$ This description misconstrues and presents an entirely unsound characterization of $\mathrm{Naz}$, as has been widely noted. ${ }^{71} \mathrm{Naz}$ engaged with foreign law in a dialogic manner, perhaps failing to sufficiently justify its usage of comparative constitutionalism. ${ }^{72}$ However, even Koushal finds an analogue in the dissenting opinions in Lawrence. Justice Scalia's dissent ${ }^{73}$ raises many such concerns, such as a focus on plain meaning interpretation (though Justice Thomas's dissent ${ }^{74}$ in Lawrence would be a better example of plain meaning analysis) and judicial caution, and like Justice Singhvi's position in Koushal, has drawn criticism for its homophobic undertones. Koushal is an outlier in the jurisprudence of the Indian Supreme Court, an example of the disingenuous application of caution in a thoroughly activist institution ${ }^{75}$, and of a "particularist ${ }^{76}$ and blindfolded approach to foreign law.

Koushal was eventually overruled by the Supreme Court in Navtej, making the arguments that took form in Lawrence the law of the land in India. This advancement was made possible primarily because of two landmark judgments, in $N A L S A^{77}$ and Puttaswamy ${ }^{78}$, both of which we will address briefly.

NALSA, which declared transgender individuals to be a "third gender, ${ }^{79}$ is notable for the extensive nature of the directions which it issued for their protection. Unlike Puttaswamy, the court in NALSA made no direct remarks regarding the position in law in Koushal. ${ }^{80}$ The Court noted the difference between the issue before it and the issue in Koushal but nevertheless fundamentally contradicted Koushal. Koushal had argued, for example, that the homosexual community was merely a 'miniscule fraction' of the population, implying that the suffering of such minorities did not warrant constitutional protection. ${ }^{81}$ Koushal seemed to implicitly create two categories of minorities in India: those large enough to warrant constitutional protection,

\footnotetext{
${ }^{70}$ ibid

${ }^{71}$ Arun K Thiruvengadam, 'Forswearing "Foreign Moods, Fads or Fashions"? - Contextualising The Refusal of Koushal to Engage with Foreign Law' (2013) 6 NUJS L REV 4 595, 599

${ }^{72}$ Sujit Choudhry, 'How To Do Comparative Constitutional Law in India' in Sunil Khilnani and others (eds), Comparative Constitutionalism in South Asia (OUP 2013)

${ }^{73}$ Lawrence (n 7) 586 (Scalia, J., dissenting)

74 ibid 605 (Thomas, J., dissenting)

${ }^{75}$ Abeyratne and Sinha (n 64) 77

${ }^{76}$ Choudhry (n 72) 58

${ }^{77}$ NALSA v Union of India AIR 2014 SC 1863

${ }^{78}$ Justice KS Puttaswamy (Retd.) v Union of India (2017) 10 SCC 1

${ }^{79}$ NALSA (n 77) 『 129

${ }^{80}$ ibid 918

${ }^{81}$ Koushal (n 62) ๆ 43
} 
and those who were not. ${ }^{82}$ NALSA noted that a "[C]onstitutional Court cannot be a mute spectator when those rights are violated, but is expected to safeguard those rights knowing the pulse and feeling of that community, though a minority, especially when their rights have gained universal recognition and acceptance, ${ }^{, 83}$ and further clarified that discrimination on the basis of "sexual orientation or gender identity" violates Article $14 .{ }^{84}$ It was "defiant" of the precedent in Koushal. ${ }^{85}$

Puttaswamy repeatedly attacks Koushal, noting that "[s]exual orientation is an essential attribute of privacy," 86 criticizing it for referring to the "so-called rights of LGBT persons" and noting that their rights were not merely "so-called" rights but "real rights founded on sound constitutional doctrine." 87 Further, it eviscerated Koushal for its "miniscule fraction" classification, concluding that it was "flawed and cannot be accepted," 88 and described Koushal as a "discordant note" in the Court's constitutional jurisprudence. ${ }^{89}$

Having addressed NALSA and Puttaswamy, two essential milestones on the road to decriminalizing S. 377, we will now attempt a brief review of the most distinctive aspects of Navtej, and place it in the context of Sonia Katyal's 'global theory of sexual sovereignty. 90

Before the central portion of our review, which focuses on the essential constitutional tests we have discussed thus far, we must take note of the general nature of our jurisprudence at this stage in its development. In a section entitled "G. The Constitution - an organic charter of progressive rights," the Chief Justice notes that the Court's jurisprudence dictates that

"the Constitution is a living, integrated organism having a soul and consciousness of its own and its pulse beats, emanating from the spinal cord of its basic framework, can be felt all over its body, even in the extremities of its limbs." $" 91$

At this stage, the Court has advanced to an extreme form of living constitutionalism, not merely personifying a legal document, but anthropomorphizing a Constitution. Characteristic of our current methodology is the assertion of two concomitant interpretive principles: that plain

\footnotetext{
${ }^{82}$ Abeyratne and Sinha (n 64) 76

${ }^{83}$ Koushal (n 62) 953

${ }^{84}$ ibid 962

${ }^{85}$ Kodiyath (n 12) 8

${ }^{86}$ Puttaswamy (n 78) 126

${ }^{87}$ ibid 9127

88 ibid 128

${ }^{89}$ ibid 124

${ }^{90}$ See Katyal (n 6) 1462

${ }^{91}$ Navtej (n 2) ๆ 82 (Misra, C.J.I)
} 
meaning may be abandoned if it regresses, or does not advance, the cause of social justice; and transformative constitutionalism, which is described as the "raison d'etre" 92 of the Constitution. ${ }^{93}$ While the Supreme Court's jurisprudence has always been heavy on grand pronouncements and ineffable doctrines, academics, as well as members of the Bar, have a responsibility to prefer disciplined legal reasoning to opulent aphorisms.

The most distinctive aspects of Navtej for the purpose of our analysis are Justice Chandrachud's Article 14 analysis, Justice Nariman's position on whether the presumption of constitutionality would obtain for pre-constitutional statutes, and Justice Malhotra's immutability principle.

We begin with Article 14. Navtej proclaims what Naz could not openly say: that equality jurisprudence was stagnant, and required expansion. What the Delhi High Court implied, the Supreme Court has, after a circuitous path, made explicit. Justice Chandrachud notes, in his judgment, that the reasonable classification test "advances the cause of legal formalism," and "risks elevating form over substance." He goes on to note that the core of Article 14 has a "substantive content on which, together with liberty and dignity, the edifice of the Constitution is built." ${ }^{94}$ Further, Bhatia notes about Justice Chandrachud's opinion that, "this is the first time that the Supreme Court has explicitly recognised the concept of indirect discrimination (i.e., where facially neutral laws - such as S. 377 - nonetheless have a disproportionate impact upon a segment of the population). ${ }^{" 95}$ Navtej is the judgment where, finally, Article 14 has "emerged out of the shadows of classification." 96

Second, the presumption of constitutionality. This distinctive exception to state deference is found in Justice Nariman's opinion, where he diverges ${ }^{97}$ from Koushal's attachment of the presumption of constitutionality to a pre-constitutional statute. ${ }^{98}$ The objection to withdrawing the presumption from colonial era statutes is found in Article 372, which continues laws in force in the territory of India immediately before the commencement of the Constitution.

\footnotetext{
92 ibid 997 (Misra, C.J.I)

${ }^{93}$ See Upendra Baxi, 'Preliminary Notes on Transformative Constitutionalism' in Oscar Vilhena and others (eds), Transformative Constitutionalism: Comparing the apex courts of Brazil, India and South Africa (PULP 2013) (for a more thorough understanding of Transformative Constitutionalism as applied)

${ }^{94}$ Navtej (n 2) 927 (Chandrachud, J.)

${ }^{95}$ Gautam Bhatia, “"Civilization has been brutal”: Navtej Johar, Section 377, and the Supreme Court's Moment of Atonement' (Indian Constitutional Law and Philosophy, 6 September 2018) $<$ https://indconlawphil.wordpress.com/2018/09/06/civilization-has-been-brutal-navtej-johar-section-377-andthe-supreme-courts-moment-of-atonement/> accessed 10 January 2019

${ }^{96}$ Navtej (n 2) 127 (Chandrachud, J.)

97 ibid 989 (Nariman, J.)

${ }^{98}$ Koushal (n 62) ๆ 28
} 
Justice Nariman, implying that there is no good reason to equate statutes passed by Parliament with colonial-era statutes, notes that "[u]nder Article 372(2), the President may, by order, make such adaptations and modifications of an existing law as may be necessary or expedient to bring such law in accord with the provisions of the Constitution." 99 The presumption of constitutionality obtains in the case of statutes passed by Parliament, he explains, because Parliament is "deemed to be aware of... constitutional limitations." ${ }^{\text {"100 }}$ In the case of a preconstitutional law enacted by a foreign legislature or body, however, no such presumption attaches. $^{101}$

Finally, we discuss what we may call Justice Malhotra's 'immutability principle.' It revolves around the notion of intrinsic or immutable traits, and reads Article 15 as prohibiting discrimination on the basis of intrinsic traits, i.e. such aspects of one's identity over which one has no control. On that basis, it is said that "[s]ex as it occurs in Article 15, is not merely restricted to the biological attributes of an individual, but also includes their 'sexual identity and character'."102 Justice Malhotra goes on to proclaim that:

"Race, caste, sex, and place of birth are aspects over which a person has no control, ergo they are immutable. On the other hand, religion is a fundamental choice of a person.27 Discrimination based on any of these grounds would undermine an individual's personal autonomy."

The immutability doctrine is "radical" ${ }^{103}$ because it prohibits, at the outset, any and all classifications based on immutable aspects of one's individuality. This is not a mere 'strict scrutiny' test based on reading Articles 14 and 15 together, but an outright prohibition on such classifications, without regard to any 'compelling state interest' or 'proportionality' test.

These innovations place Navtej in the upper echelons of our constitutional jurisprudence, but the significance of Navtej is better understood in the context of a larger story, one that is crossjurisdictional and interdisciplinary. Lawrence, once decided, had an "underlying theme of sexual self-determination, or sexual sovereignty." 104 In her work, Sonia Katyal enumerates the elements of such a theory, which "offers a trilogy of protections," consisting of Spatial Privacy,

\footnotetext{
${ }^{99}$ Navtej (n 2) ๆ 90 (Nariman, J.)

100 ibid

101 ibid

102 ibid 915.1 (Malhotra, J.)

${ }^{103}$ See Bhatia (n 95)

${ }^{104}$ Katyal (n 6) 1461
} 
Deliberative Autonomy, and Expressive Liberty. ${ }^{105}$ Let us consider Indian jurisprudence within this framework.

First, Spatial Privacy, according to Katyal's characterization of Lawrence, is both positive and negative: consisting of cordoning off the home from state interference, as well as a fundamental right to engage in sexual intimacy. ${ }^{106}$ Now, let us return to the Chief Justice's opinion in Navtej, where he consecutively quotes Article 12 of the UDHR ${ }^{107}$, Article 17 of the ICCPR ${ }^{108}$, the European Convention on Human Rights ${ }^{109}$, and refers to the definition of privacy involving the "right to be let alone." ${ }^{110}$ All of these international instruments refer to the negative concept of spatial privacy, prohibiting intrusions into the home. In the immediately consecutive paragraph, the Chief Justice notes the following:

"There can be no doubt that an individual also has a right to a union under Article 21 of the Constitution. When we say union, we do not mean the union of marriage, though marriage is a union. As a concept, union also means companionship in every sense of the word, be it physical, mental, sexual or emotional.",111

Spatial Privacy involves, in Indian Jurisprudence, the full realization of its potential. The Right to Privacy combined with the Right to a Union identifies in a more accurate and comprehensive manner the notion of Spatial Privacy, as outlined in Katyal's framework. However, Katyal is careful not to be reductionist and notes that spatial sovereignty has its limitations in the global context, where "issues of space, identity, and the boundaries between public and private can often vary widely," 112 carrying significant repercussions for those "who cannot enjoy the protections of privacy within the home, particularly in a joint family context." This is a telling critique that holds true in India. Katyal's framework, however, maps perfectly onto Justice Chandrachud's opinion, which notes that "even the conception of a private space for certain individuals is utopian," 113 and declaring that "[ $t]$ he right to sexual privacy, founded on the right to autonomy of a free individual, must capture the right of persons of the community to navigate public places on their own terms, free from state interference." 114 Second, Deliberative

\footnotetext{
105 ibid 1463, 1472, 1478

${ }^{106}$ ibid 1465

${ }^{107}$ Navtej (n 2) 150 (Misra, C.J.I)

108 ibid 151 (Misra, C.J.I)

109 ibid 152 (Misra, C.J.I)

${ }^{110}$ ibid 153 (Misra, C.J.I)

111 ibid 155 (Misra, C.J.I)

${ }^{112}$ Katyal (n 6) 1469

${ }^{113}$ Navtej (n 2) 61 (Chandrachud, J.)

114 ibid 92 (Chandrachud, J.)
} 
Autonomy, in this case, concretized as 'sexual autonomy' centers “on the freedom to seek sexual fulfillment and freedom from sexual coercion." 115 The freedom to seek sexual fulfillment is addressed by the Chief Justice's discussion of the Right to Union, and the freedom from sexual coercion is addressed in the same paragraph:

"The LGBT community is seeking realisation of its basic right to companionship, so long as such a companionship is consensual, free from the vice of deceit, force, coercion and does not result in violation of the fundamental rights of others."

Further, Justice Nariman notes, in his opinion, that "the right to life and liberty would encompass the right to sexual autonomy," 117 stating that LGBT persons "are entitled to complete autonomy over the most intimate decisions relating to their personal life, including the choice of their partners." 118 Third, Expressive Liberty is an integral part of Navtej. Justice Chandrachud writes:

"It is for this reason that constitutional morality requires this court to issue a declaration - which we now do - that LGBT individuals are equal citizens of India, that they cannot be discriminated against and that they have a right to express themselves through their intimate choices."119

The Chief Justice also centers expression in dignity, declaring that it was the Court's constitutional duty to allow individuals to "express himself/herself, of course, with the consent of the other." ${ }^{120}$ Further, the Chief Justice's holding contains "the right to express and choose without any impediments." 121

It is curious that a 'utopian reading' ${ }^{122}$ of Lawrence outlined in 2006 maps completely onto the Indian Supreme Court's LGBT Rights jurisprudence. Perhaps this is because of a 'universalist' approach of comparative constitutionalism. The fundamental insight to be extracted from the saga of S. 377 is the importance of the incrementalist approach to statutory interpretation. The holding in Navtej and the realization of Katyal's work in Indian Law was made possible by a long series of cases, many initially dismissed as bleak horizons in constitutional law. Finally,

\footnotetext{
${ }^{115}$ Katyal (n 6) 1472

${ }^{116}$ Navtej (n 2) 155 (Misra, C.J.I)

117 ibid 29 (Nariman, J.)

118 ibid

119 ibid 9145 (Chandrachud, J.)

${ }^{120}$ ibid 132 (Misra, C.J.I)

121 ibid 9253 (Misra, C.J.I)

122 Katyal (n 6) 1490
} 
it is not just the holdings in individual cases that is at issue in this analysis, but the steady, incremental, effort of evolving law for history.

A few conclusory notes of caution are, however, required: the expansive reading of Article 14, the unbounded blunt instrument that is Constitutional Morality, and other reasons for judicial holdings borne not out of constitutional provisions but undefined principles intuited from the Constitution's structure and object - these are important changes in jurisprudence that must not go unexamined. Unless the prudence of the applications of these doctrines and a stable foundation for constitutional adjudication is articulated, it will be difficult to judge future cases purely on their legal and jurisprudential grounds. The internal consistency of doctrine, and of cases with their precedents, and the logical continuity of legal analysis is the only barrier against anarchy in law. ${ }^{123}$

The evolution of law, keeping pace with social standards and beliefs of a populace, is part of the nature of a democracy. A legislature can, of course, oppose social beliefs and attempt to eradicate even widespread social evils in a progressive lawmaking exercise. For the judiciary, for the least dangerous branch, that is meant to represent neither 'force nor will but mere judgment' to do so is a matter requiring careful consideration and significant pragmatism, balancing the conflicting concerns enshrined in the separation of powers and a system of checks and balances. This is where the search for the takes form. It is the abandonment of responsibility for reasoned decision making and the endless search for the additional level of abstraction, the new interpretation within the closed list, the metamorphosing meanings of statutory text, and the newfound addition to a jurisprudential test. It is the search for a richer and more expansive jurisprudence rather than a clearer one. Not until 'complete justice' as defined by the judiciary of the day is achieved and all actualities have been mastered will the search come to an end. Until then, the judicial analysis in the Republic of India continues to be a groping search at the edge of the dark for the new new thing. The Republic will be better off for it. Its jurisprudence, however, will not.

\footnotetext{
${ }^{123}$ Antonin Scalia, 'The Rule of Law as a Law of Rules' (1989) 56 University of Chicago Law Review 41175 , 1180 ("It is a commonplace that the one effective check upon arbitrary judges is criticism by the bar and the academy. But it is no more possible to demonstrate the inconsistency of two opinions based upon a 'totality of the circumstances' test than it is to demonstrate the inconsistency of two jury verdicts. Only by announcing rules do we hedge ourselves in.")
} 